This is the accepted (post-print) version of the following published article:

Kahu, E. R., Stephens, C. V., Zepke, N., \& Leach, L. (2014). Space and time to engage: Mature-aged distance students learn to fit study into their lives. International Journal of Lifelong Education, 33(4), 523-540. doi:10.1080/02601370.2014.884177

\title{
Space and time to engage: Mature-aged distance students learn to fit study into their lives
}

Ella R. Kahu, Christine Stephens, Nick Zepke, \& Linda Leach

\begin{abstract}
Student engagement, a student's emotional, behavioural, and cognitive connection to their study, is widely recognised as important for student achievement. Influenced by a wide range of personal, structural, and sociocultural factors, engagement is both unique and subjective. One important structural factor shown in past research to be a barrier for distance students is access to quality space and time. This qualitative study followed 19 mature-aged distance students and their families, exploring how they learned to manage their space and time throughout their first semester at university. Institutions often claim that distance study and the increased use of technology overcomes barriers of space and time; however, the findings from this study suggest it merely changes the nature of those barriers. The ideal space and time for these students was individual and lay at the intersection of three, sometimes competing, demands: study, self, and family. A critical influence on success is family support, as is access to financial resources. Learning what constitutes ideal space and time for engagement is an important part of the transition to university. The institution has a vital role to play in aiding this process by ensuring flexibility of course design is maintained, providing more flexible advice, and targeting support at this important issue.
\end{abstract}




\section{Space and time to engage: Mature-aged distance students learn to fit study into their lives}

Student engagement, a student's emotional, behavioural, and cognitive connection to their study, is an important construct that is widely recognised as being central to student achievement and satisfaction (Trowler \& Trowler, 2010). Described as a meta-construct, student engagement draws together diverse threads of research that aim to explain student success (Fredricks, Blumenfeld, \& Paris, 2004). While there is debate in the field over exactly what constitutes engagement, all would agree that student engagement is an embedded phenomenon, influenced by a range of university and student factors, as well as the sociocultural context, and resulting in both academic and personal gains (Kahu, 2013). The literature has tended to focus predominantly on the influence of university factors, but students come to university with very different backgrounds and lives and this also influences their engagement with their study. A recent review concluded that there needs to be more holistic research into the student experience that links academic learning with the rest of the student's life (Ertl \& Wright, 2008). The current research aimed to do that by exploring one important structural influence on distance students' engagement with their study - access to space and time.

Flexibility is seen as the cornerstone of contemporary higher education (Selwyn, 2011) and the increase in distance education has been hailed as an enabler of lifelong learning (Jarvis, Holford, \& Griffin, 2003). More recently, technology has improved the digital delivery of learning materials, which some have claimed makes learning more accessible, an idea that is not without its critics (Gorard, Selwyn, \& Madden, 2003). Jarvis et al. (2003) describe traditional education as involving barriers which regulate when and where learning takes place, in terms of timetables and classrooms, and suggest that open and distance learning changes 'the fundamental categories of time, place and space in which learning occurs.' (p. 116). Others make even stronger claims, suggesting that elearning has 'power in overcoming time and space barriers' (Redecker, Ala-Mutka, Bacigalupo, Ferrari, \& Punie, 2009), and 'allows students to learn without limitations of space and time' (Cheng, Wei, \& Chen, 2011, p. 260).

This flexibility appeals particularly to mature aged students (defined as over 24 years). In New Zealand, a third of all bachelor degree level students are mature aged and a third of those choose to study extramurally (Ministry of Education, 2011). These students often have very full and complex lives; they have full or part time paid work, and they have partners and/or children and other family and community commitments. Because of this, distance study, with no requirement to attend a campus at specific times, theoretically makes it easier to fit study into their lives. However, while mature aged students have similar course pass rates to younger students, their first year attrition rate is higher (Ministry of Education, 2011). This reflects the finding that the transition to university is a challenging process, particularly for older students (Baxter \& Britton, 2001; Henderson, Noble, \& De George-Walker, 2009). 
It has been suggested that while flexibility can be seen as a virtue, enabling multitasking and fluidity of roles, it can also be seen as a curse, impacting negatively on family life and creating new stress (Servage, 2007). For example, an increasing body of research into work/life balance has examined how technology blurs the boundaries between paid work and the home and the impact this has on the management of space and time (Kaufman-Scarborough, 2006). Setting boundaries around paid work becomes necessary to attain a satisfactory work/life balance (Currie \& Eveline, 2011). Distance study presents a similar difficulty, the blurring of boundaries between study and home, yet few researchers have examined distance study from this perspective. One notable exception is Moss (2004) who argues that space and time are useful concepts to examine experiences in higher education in order to reveal 'the intricate daily action involved in studying' (p. 284).

Traditional on campus study, for all its inflexibility, provides students with appropriate learning spaces and scheduled time which, together, enable students to step away from other commitments for sufficient time to facilitate deep engagement with their study (Servage, 2007). Learning at home, on the other hand, is often done alongside people and activities, squeezed into smaller spaces and times (Moss, 2004). As Selwyn (2011) says, the claimed flexibility of distance study is not manifested in the daily struggle of 'finding appropriate temporal and physical contexts in which to learn' (p. 378). It can be argued that distance study has not overcome the barriers of space and time; it has merely changed the nature of those barriers. Previous research has identified role overload and time management as key obstacles to successful study for mature aged students (Baxter \& Britton, 2001; Urquhart \& Pooley, 2007). In particular, research has focussed on female students and their struggle to balance their caregiving responsibilities with their study, a dilemma often linked to cultural gender roles (Alsop, Gonzalez-Arnal, \& Kilkey, 2008; Ayres \& Guilfoyle, 2008; Christie, Tett, Cree, Hounsell, \& McCune, 2008). While time is widely recognised as a barrier, only a few studies have included space or looked closely at how students manage this process in the transition to university.

Moss's (2006) analysis showed how women 'carved out space and time from others' space and time and created different places to study' (p. 202). The women studied in a wide range of places, determined in part by personal preference and in part by circumstances. According to Moss (2006), the availability of space and time is shaped by gender and social position, and women's agency over their activities is critical to their ability to create the necessary space and time for higher education. Lowe and Gayle (2007) looked more specifically at students' strategies and developed a typology of four different approaches based on the degree of blurring between study and work/family and the students' success at managing. From the most to the least successful, the strategies were: separation, study had little impact on other activities; integration, study was fitted into life with negotiation and support; overlap, characterised by ongoing negotiation and imbalance; and finally conflict, instability from conflicting demands and stress. The authors identified support as one of the key influences on students' success at balancing study, work, and family. 
The current paper builds on these studies in a New Zealand context. The wider research project followed a group of first time, mature-aged distance students and their families through their first semester at university, exploring student engagement and its influences. This paper asks how the students and their families learned to manage space and time in that first semester.

\section{Method}

This qualitative study took an interpretive approach that studies people in their natural settings, 'attempting to make sense of, or interpret, phenomena in terms of the meanings people bring to them' (Denzin \& Lincoln, 2005, p. 3). The complexity of the student experience lends itself to a critical realist perspective, which recognises that the social world is an open and complex system, which cannot be counted or measured but rather must be interpreted and understood (Sayer, 2000).

\section{Participants}

Invitations to participate in a study of student engagement were sent to 400 first year distance students over the age of 24 enrolled in the first semester of 2012 at a New Zealand university. Of the 75 who responded, 25 met the criterion of being first time university students and, of those, 19 were available for the scheduled interviews (see Table 1). The four male and fifteen female participants were diverse in terms of age ( 25 to 59), family structure (single, couples, two parent families, single mothers, and those with adult children), and ethnicity (fifteen New Zealand European, five Maori, two Asian and one Cook Island; a number identified as multiple ethnicities). All relationships were heterosexual. The majority were taking arts or business courses; three were taking the equivalent of a fulltime workload, thirteen were doing approximately half time, and three were taking a single course. One participant had some experience with distance learning.

\section{Data collection}

The participants along with 11 partners, and 10 children aged over five, were interviewed by the first author in the four weeks prior to the semester starting. The semi structured interviews averaged 90 minutes and focussed on their preparation, expectations, and motivations for study. Participants then kept diaries, approximately weekly, throughout the first semester. Sixteen completed Skype video diaries from their home computers. Video diaries were used as they potentially access a more personal account of the student experience and the immediacy allows the capture of details that may later be forgotten or seen differently in hindsight (Willig, 2001). One who did not have sufficient internet access was given a handheld camera, and two chose to write email diaries. The students talked about their engagement with their study - how they were feeling, behaving, and thinking - and commented on what they felt was influencing those experiences. Each week, the first author listened to the diaries and emailed the student comments and/or prompts for future diary entries. After the semester, follow up interviews were conducted with 13 students and their families drawing in part on data from the diaries. Four students who withdrew from their courses early in the semester had 
telephone second interviews, and two students were not available for a second interview. The fully transcribed interviews and diaries were returned to the participants for approval.

Table 1

Participant details

\begin{tabular}{|c|c|c|c|c|c|c|}
\hline Pseudonym & $\begin{array}{l}\text { Gender } \\
\text { Age }\end{array}$ & Ethnicity & $\begin{array}{l}\text { Family } \\
\text { (at home) }\end{array}$ & Paid work & Study & SES \\
\hline Alfie & F 33 & $\begin{array}{l}\text { Maori } \\
\text { NZ European }\end{array}$ & $\begin{array}{l}\text { Partner } \\
1 \text { preschool } \\
1 \text { school aged }\end{array}$ & $\begin{array}{l}\text { Casual } \\
\text { Part time }\end{array}$ & Full time & Low \\
\hline Bella & F 39 & Asian & $\begin{array}{l}\text { Partner } \\
1 \text { school aged }\end{array}$ & & Half time & Moderate \\
\hline Bex & F 27 & $\begin{array}{l}\text { NZ European } \\
\text { Maori }\end{array}$ & None & Full time & Half time & Low \\
\hline Brad & M 48 & NZ European & $\begin{array}{l}\text { Partner } \\
1 \text { school aged } \\
\text { (part time) }\end{array}$ & Full time & Half time & Moderate \\
\hline Charlotte & F 25 & NZ European & Partner & Full time & Half time & Moderate \\
\hline Daniel & M 26 & $\begin{array}{l}\text { NZ European } \\
\text { British }\end{array}$ & Partner & Full time & Half time & Moderate \\
\hline Jeremiah & M 51 & NZ European & Partner & & Half time & Low \\
\hline Kaitlyn & F 36 & $\begin{array}{l}\text { Maori } \\
\text { Cook Island }\end{array}$ & 2 school aged & $\begin{array}{l}\text { Home } \\
\text { schooling }\end{array}$ & Full time & Low \\
\hline Lexi & F 26 & NZ European & $\begin{array}{l}\text { Partner } \\
1 \text { school aged } \\
3 \text { preschool }\end{array}$ & & Half time & Moderate \\
\hline Maria & F 36 & NZ European & $\begin{array}{l}\text { Partner } \\
1 \text { preschool }\end{array}$ & & Half time & Moderate \\
\hline Marie & F 38 & NZ European & 1 school aged & Full time & Quarter time & Low \\
\hline Melissa & F 46 & NZ European & $\begin{array}{l}1 \text { primary } \\
1 \text { school aged }\end{array}$ & Part time & Quarter time & Low \\
\hline Natasha & F 38 & NZ European & None & Full time & Full time & Moderate \\
\hline Penny & F 59 & NZ European & None & Full time & Half time & Low \\
\hline Samantha & F 33 & NZ European & $\begin{array}{l}\text { Partner } \\
2 \text { school aged } \\
1 \text { preschool }\end{array}$ & PT (started) & Half time & Low \\
\hline Sarah & F 25 & NZ European & $\begin{array}{l}\text { Partner } \\
1 \text { preschool } \\
1 \text { school aged }\end{array}$ & & Full time & Moderate \\
\hline Scott & M 38 & Maori & $\begin{array}{l}\text { Partner } \\
1 \text { preschool } \\
2 \text { school aged }\end{array}$ & Full time & Half time & Moderate \\
\hline Toni & F 52 & $\begin{array}{l}\text { NZ European } \\
\text { Maori }\end{array}$ & 1 adult child & Full time & Half time & Low \\
\hline Vee & F 37 & Asian & $\begin{array}{l}\text { Partner } \\
2 \text { school aged }\end{array}$ & & Quarter time & Moderate \\
\hline
\end{tabular}

Note: SES based on family occupations

\section{Data analysis}

The thematic analysis took a theoretical interpretive approach and identified themes from surface meanings, taking language as a simple and neutral expression of people's experience, while paying heed to the social context (Braun \& Clarke, 2006). During the initial data coding phase, aimed 
at identifying the different influences on the students' engagement, a notable theme that emerged was the students' struggle to find quality space and time.

\section{Findings}

The analysis shows that managing space and time is a learned skill; students had to experiment with different spaces and times to discover what worked best for them. In addition, home is not a dedicated learning space; it is shared with other people and with other roles. The students trialled different strategies to access sufficient space and time that was of the quality they needed to study. Some were successful in this learning while others decided they couldn't or didn't want to make the adjustments necessary. Support was an important influence on their success.

\section{The right time}

The university website advises students that distance study 'provides the flexibility many students need to fit with today's changing lifestyles. You simply study when, where and how you want to.' This flexibility was the key reason the students chose distance study: they had jobs and/or children, or they lived in rural areas and so could not attend a university campus.

Most of the students began the semester believing it was simply a matter of 'finding' the time and setting up a desk. The university recommends 10-12 hours per week for each paper and a number of online tools are available for students to assess their lifeload prior to enrolment. However, none of the students had used these tools and their awareness of the workload expectations varied dramatically from Melissa, taking one course after carefully considering her lifeload, to Natasha, taking a full time load while working full time. Some only realised how many hours were expected after they enrolled, while others simply didn't believe the recommendation:

They say 25 hours for two subjects, which is ridiculous, because a full time student is doing 50 hours which you know they're not. So I think, I'm hoping 8-10 hours will be enough. (Brad)

While most students took the general demands on their time into account when deciding how much study to take on, lifeload was not stable and most students experienced times during the semester when finding quality time was particularly challenging due to changing work and family demands, such as school holidays and illness.

As the semester progressed, students learned not just how much time they required for successful study but also what kind of time they preferred. For some, they found they could study better in larger chunks of several hours, whereas for others regular breaks were critical to their engagement. Time of day was also important for some of the students, finding that they were too tired in the evenings, for example. 


\section{The right space}

In terms of space, at the start of the semester most of the students felt they should have a separate study space, following the university and common knowledge view that study is best done in isolation. Their ability to do this depended on their living arrangements: three students lived alone, three had a separate study, six set up desks in their bedrooms, six planned to study in shared living spaces and one planned to study at work after hours.

Increasingly, study resources are digital rather than print, and therefore an important requirement for a quality space was access to a computer and internet. Computers, however, were often shared with other family members, constraining where the study took place and limiting access when others were home. In addition, three students had serious internet connection problems during the semester. The worst affected was Scott who moved house and had no connection for two months: 'So, I couldn't get online except for at work and I can't exactly study at work.' Studying in public spaces was also constrained at times by the need for internet access.

Importantly, and contrary to university advice, it quickly became apparent that, aside from technology requirements, there was no one right space. The students had to learn what they needed for a quality learning space; as Daniel says, 'you have to experiment with study to find what works for you'. Some students started the semester with a clear idea of their personal needs and were able to set up their homes accordingly. For example, Jeremiah, who lived with his partner, had the use of the spare room as a study, while Marie, who had a teenage son, knew she could study at the dining table: 'I'm reasonably good at working and ignoring what's going on around me'.

In contrast, other students experienced a tension between what they thought they should be doing, and what worked for them. These students felt isolated in their study or bedroom and found this interfered with their ability to focus on their study: 'I felt like a little bit of a manic depressive, holed up in my bedroom'(Samantha). This was a learning process and some fought against their preference:

I had originally planned to do a lot of it in our spare room but I found when I did that, I would look for things to distract myself... So I started doing it out here [lounge] and I found, with just having the TV on in the background, I ended up getting a lot more study done. It was really weird. (Charlotte)

I wanted to be here [the lounge] but my study space was in there, but I didn't like it feeling isolated, which it kind of should be for study ...the study space was not working for me. And I wasn't very conscious of that, it was an unconscious struggle between where I wanted to be and where I felt like I was supposed to be. (Sarah)

The preferred noise level in study spaces was another factor that surprised the students and Charlotte was not alone in finding she could engage more effectively with a certain level of background noise. For some, television in the background was useful while for others it was a 
distraction. Natasha's comment illustrates how the students had to experiment to find their ideal conditions:

I've been trying to find ways in which I can concentrate on my study. Tried music, tried noise, tried TV, tried silence, nothing worked. Then one day I had my Mascar going, my motorsport, and sure enough, instant focus, read for hours. (Natasha)

The ideal space and time therefore was personal. What the students needed to effectively engage with their studies depended on their study, their family, and their own preferences.

\section{Shared space and time}

A barrier to finding the ideal space and time for study was that home was not a dedicated learning space and the students' time was not dedicated solely to study. As well as being shared with other people, the home was also associated with different roles - parenting, domestic chores, and relaxation - and these roles impacted on study. Parents faced a particular challenge, especially those with young children who found it very difficult to study while children were home and awake. Even adult children impacted. For example, when Toni's youngest son came home from university she reverted to her parent role: 'I just do what I normally do when he's around, for him... that's what I choose to do, is to spend time with him.'

Domestic chores also represented a significant distraction for students. While most partners supported the students by taking over a greater share of the chores, studying at home was still made difficult by the presence of undone household chores:

I found the gym was a really good place to study because I'm not sitting at home, I'm not looking at the windows going, they need cleaning, I'm not looking at the ceilings going Oh God and I'm not looking at my massive washing pile going, shit I need to fold that. (Lexi)

Home was a place of relaxation making it difficult to focus for some students. For example, Natasha, a shift worker, experienced a very clear distinction between what she called her work and home modes and therefore her 'good' work was mostly achieved when she was at work:

Whereas quite often you can be sitting at home, like I'll sit here and the birds, oh look at the pretty, oh the pretty clouds (laughs) because you're in that relaxed state, if that makes sense, you're in your, at home, ... so I think that's why, I got probably most of my good work done, actually at work. (Natasha)

Learning space is concrete and measurable; students can mark it out and allocate it, they can physically shut themselves away. Time is less tangible but was made real by the students through the use of metaphor. And, as Lakoff and Johhson (1980) point out, metaphor does more than just describe the world, it structures our understanding of it. The metaphor of time as a valuable and limited resource is widely used and recognised in western culture (Lakoff \& Johnson, 1980) and this was very evident in the students' talk where time was variously described as precious, limited, squeezed, spent, 
or wasted. Unlike space, which was shared, time was described as belonging to specific people. Sometimes it was theirs: 'I can choose to use my time as I want' (Melissa); and at other times it belonged to the family: 'Come three o'clock it's children time'(Melissa).

Time was accordingly described as given or taken. For example, both study and family were described as taking time from the student, paralleling past researchers who have described family and education as 'greedy institutions' (Edwards, 1993; Vaccaro \& Lovell, 2010). For example, Lily, Daniel's partner, was 'surprised at the time that it's taking out of his life', while Toni described her son as 'taking the time that I was going to use'.

\section{Successful strategies}

As they progressed through the semester, the students learned what temporal and spatial conditions they needed to study successfully and how to create those conditions. Three key strategies were used: temporal separation, scheduling study when the home was empty; physical separation, either by shutting themselves away within the house or by taking the study elsewhere; and dovetailing, studying alongside other people and roles. Most students used a mix of strategies but tended to have a preferred approach, determined in part by personal preference but also by lifeload and support.

\section{Temporal separation}

For many parents, particularly those not in full time work, a key strategy was temporal separation, studying only when the children were at school or in bed. This gave them a quality learning space and also allowed them to prioritise their parenting role. This was Melissa's preferred approach: 'I didn't want them to be disadvantaged. So three o'clock came, all study stopped.'

While this approach was ideal for effective engagement, in that it gave blocks of interrupt free time, it was not always easy. It depended on having sufficient hours in the week with no competing roles, and particularly with younger families, balancing everyone's schedules was difficult:

I've done a hideously complicated looking schedule which gives me, I think it was 28

to 35 hours a week... so I am not trying to study when they are in the house because that will do my head in. (Sarah)

\section{Physical separation}

Sometimes there simply wasn't time available when the home was empty, leading to a strategy of physical separation; either by separation in the home or by studying away from home. Most students used this approach when assignments were due and finding ideal space and time was essential for full engagement:

I know this weekend I'm gonna be, well I better be, locked away somewhere all by myself because I'm gonna need that time just to put everything together. (Vee) 
Brad and Scott used this approach on a more regular basis. Scott and his wife, who was a full time student, went away for alternate weekends to the family's holiday home while Brad opted to stay at work for two to three hours each night: 'Because the place will be quiet, because there will be no one there... there is a proper computer to use'. In both cases this was a successful strategy in terms of their engagement, they had a quality learning space, but both found it very difficult because they saw less of their families: 'It was hard, the first weekend was really hard. To be away from the kids and everything' (Scott).

\section{Dovetailing}

While temporal or physical separation can give ideal space and time, the students had busy lives and often could not cleanly separate their study. More time was needed and so the other key strategy was dovetailing, weaving study into smaller spaces and time alongside other roles. Samantha described how studying in the lounge enabled her to parent while studying:

Because you know, if the kids are fighting I can see what they're fighting over or you know, what everyone's doing... and I can just flick an eyebrow if I'm out here.

\section{(Samantha)}

Lexi's children had a range of illnesses throughout the semester and she became an expert at studying in hospital waiting rooms and cafés. The lower level of engagement possible in dovetailed time is evident in her comment that the work she managed to do was not her best:

I did manage to sit in the hospital cafe and, I think in the two and a half hours she was in surgery I think I got about 7 or 800 words done. Which, it wasn't that good so quite a lot of it got rewritten but it was still the basic ideas and everything. (Lexi)

Students also made the most of their time by overlapping study with relaxation and with chores. For example, they read or listened to podcasts while in the bath, on family outings, and cooking dinner. Those in paid work also fitted study into lunch hours or quiet times. The quality of the space and time available depended on the nature of their work and on support from colleagues:

I guess my work was pretty supportive of it, like they gave me a room to use during my lunch breaks just so I could get away from everybody, because I sit out at the front desk and if I sit out there during lunchtime I get people interrupting me all the time and it gets really frustrating. (Charlotte)

While dovetailing enabled extra study hours, the fact that it was often smaller amounts of time in shared spaces meant it was not ideal and it was therefore harder to engage at a deeper level. As Melissa said: 'it's just winging it, I'm not, it's not full blown concentrated study'. One way the students compensated for this problem was assigning lower level tasks to dovetail times: 'The days when the twins are home they can play quietly so I can do simple tasks like reading and stuff' (Lexi). 


\section{Family support for access to space and time}

As the student learned what space and time was needed for study, and what they personally needed, partners and children learned to adjust. In talking about what made it better, families emphasised the importance of communication, mutual support, and being flexible. According to Jeremiah's partner, the most important thing partners could do was: 'Just give them all the space they need for their study, support them, you will tend to know and find out when they're engrossed in their study and not to disturb them' (Jennie). Partners taking on a greater share of chores and childcare to free up time was also important: 'it was a given that when I got my books out he pretty much cooked dinner and washed the dishes and stuff'(Charlotte).

One measure of support was how much control students felt they had. While all the students expressed themselves as being in control of their time sometimes and not in control at other times, some stood out as having particularly strong agency, able to manage the people in their lives in order to get what they needed. This was linked to lifeload but also to effective partner support, and for these students, space and time were more readily available. For example, Lexi, despite living on a farm with her husband and four young children, told her family they could not interrupt when the door was closed and said: 'it wasn't that hard, you just sort of, you know, set aside your time and say right, I need to get this, this, and this done today'. Jeremiah too, with no children at home, no paid work, and a very supportive partner, had complete control over his time: 'My study doesn't necessarily interfere with anything that we do, and she doesn't interfere with my study.'

Others had noticeably less support and therefore less control. Their study had a lower priority within the family and they did not have the power necessary to 'find' or 'make' the needed space and time. For example, Scott worked full time and in the evenings the children were his responsibility: 'It's just there is so much going on and it is difficult to do it when Denise is doing it [studying] as well and you know obviously one of us has to look after the kids.'

At times, a number of partners expressed frustration that their own activities were limited by study taking space and time:

One, I feel that the dining room table is taken up by things that don't belong on the dining table and two, it does kind of restrict that I can't just go to the piano and play because I know that he finds noise distracting. (Daniel's partner Lily)

Tolerating this kind of impact was a key support. Despite her annoyance, Lily didn't pressure Daniel to take his study to the spare room. In contrast, Samantha's partner pressured her to reduce her study time because of its impact on his life:

I think that Steven is starting to struggle with the fact that it's taking time away from him when he gets home from work and um, he sort of had suggested that I was doing a little too much. (Samantha)

Once Samantha's husband gets home from work, time belonged to him and therefore study was 'taking' it from him. Samantha had little agency in the relationship. She commented that Steven 
didn't appreciate the value of what she was doing and eventually, on his suggestion, she took on part time work. This of course further reduced the time she had available for her study.

If time belongs to other people, then guilt for taking it can be seen as a logical consequence. Samantha and other mothers expressed guilt for spending time with their study rather than their children, and in Samantha's case, her husband. Maria was asked what the most important influence on her study was:

Having the ability to um, organise our lives in such a way that I can have a small block of time in the day to make it happen... having time that didn't make me feel guilty that I was taking time away from [my son] or family. (Maria)

This suggests Maria feels she has control not just over her own life but others in the family too. But alongside this apparent control, is the idea that at least some of her time belongs, by default, to her family and that if she 'takes' that time then she will feel guilty and therefore be unable to study as effectively.

Developing and trialling these strategies was part of the first semester's learning. For some students, the journey was short and unsuccessful. They decided quickly they were not willing or able to make the changes necessary and they withdrew in the first few weeks. For others, the end result was success. They learned how to juggle and negotiate with their families to carve out sufficient space and time. These students passed and most are continuing with their study. And for some students, the semester was a long and drawn out battle. They persevered but a lack of control over their lives, poor support from family, and unexpected life events meant that they were unable to find the space and time necessary. These students withdrew late in the semester or failed. A key factor influencing student success was support.

\section{Discussion}

These findings shed light on key issues facing first year mature aged students in their first semester of university. The students start the semester with fixed ideas about space and time, taking on board university messages that they can 'simply study when, where and how you want to'. The reality, however, is that they have complex lives and a major challenge they face is learning how to find the space and time necessary. There is no one correct approach and each student must experiment - trialling different ways of studying and gradually learning what works for them, what works for their study, and what works for their family.

The ideal spatial and temporal conditions for engagement lie at the intersection of these three, sometimes competing, demands. Firstly, other than university advice of 12 hours per course and a separate desk, students do not know at the start what study needs in terms of space and time. As the 
semester progresses, however, they begin to learn more, including distinguishing between those study tasks that require ideal conditions and those tasks that can be done when the conditions are less than ideal. An important aspect of study's requirements is a space with internet access and, as Kirkwood (2000) also found, technology is often located in shared spaces and shared by other family members. This finding supports Rye's (2007) conclusion that technology, rather than contributing to flexibility as is often claimed, can actually reduce it.

Secondly, these students are often new to study and do not yet know what conditions make it easier or harder for them to engage with the course. They must experiment with variables such as physical spaces, times of day, and length of study sessions to learn how these factors affect their engagement. Finally, the students must decide what priority they give to their family and to their study, and they must work with the family to negotiate spaces and times from everyone's home and lives.

As the students came to appreciate the requirements of study, their own preferences, and their family routines, they developed strategies to enable as much ideal space and time as possible. Temporal separation, studying at home while the family are out, is a useful strategy because it enables blocks of time in an empty home, a high quality environment that enables students to engage deeply with their study. This approach requires less adjustment by the family but it relies on there being times when the home is empty. Other research has found this to be the commonest strategy for mothers (Brooks, 2012; Christie, Munro, \& Wager, 2005). Physical separation, either by shutting oneself away in the home or by studying elsewhere, was used by all the students at times, particularly approaching assessments. However, this approach is highly dependent on other people's support: taking on tasks of parenting and chores, respecting the space by not interrupting, and accepting the absence of the student at traditional home times of evenings and weekends. When neither temporal nor physical separation could enable sufficient time, students resorted to dovetailing, weaving study into smaller spaces and times alongside other tasks and roles. Research into women's experiences as mature aged students highlights the common use of this strategy (Moss, 2006; Vaccaro \& Lovell, 2010). While dovetailing relies less on other people, the space and time it creates are often less than ideal for effective engagement. This time is therefore better used for less demanding study tasks. This finding aligns with Lowe and Gayle's (2007) research, which found that compartmentalisation, keeping study separate from other roles, was the most successful strategy and overlapping approaches, requiring negotiation with others, were generally less successful.

Support from family is a key influence on the quality and quantity of space and time a student has and therefore their choice of strategy. Others have noted that family support is important for mature aged students (Kember, 1999; White, 2008; Zepke, Leach, \& Butler, 2011), but few studies have defined support or explored how it impacts on student success (Castles, 2004). Kember (1999) describes a supportive family as one that willingly adapts its lifestyle to facilitate study and this is evident in the current findings. In addition, the findings suggest an important mechanism by which 
support aids student success is by giving the student control so they don't need to ask the family for time or space; instead it is theirs to allocate. This parallels Moss's (2006) finding that agency is critical. In families characterised by this type of support, study is given a high priority and it is assumed that the partner will take on a greater load of the domestic work. The student, therefore, does not need to ask for time when they need it. It was notable that while all the partners said at the start that they intended to support the student, some were unsure what support would entail, and others failed to put that intention into action. Bird and Morgan (2003) argue that it is difficult for students to envisage the impact of study on their families and that the sooner they begin the process of negotiation with the family, the better.

As Moss (2006) points out, access to space and time is influenced by broader social issues such as gender and class. In particular, past findings have highlighted the difficulties women have fitting in study because of the cultural assumption that they are the primary caregivers (Alsop et al., 2008; Christie et al., 2005). In the current study, the women were usually the primary caregivers; however, this generally only limited their access to space and time when they were sole parents or lower socioeconomic status. While past studies have commented on women students receiving inadequate support from husbands (Ayres \& Guilfoyle, 2008; Baxter \& Britton, 2001; Zembylas, 2008), in this study it was interesting to note that, in two parent families and couples without children, the degree of support offered by partners varied as much within genders as it did between genders. One area where gender difference was apparent, however, was the expression of guilt; only the mothers expressed guilt for not spending sufficient time with the children, a finding paralleled in other research (White, 2008). Unfortunately, with only four male participants, and only one of those with children full time, it is difficult to comment further on gender differences. Further research with more male participants would be valuable.

Particularly for students with children, socioeconomic status was an important contextual variable that influenced access to space and time in multiple ways. Firstly, when the family were on government benefits or in low wage jobs, the student felt the need to complete a qualification as quickly as possible. This meant they tended to take on more courses and consequently struggled to find sufficient time. Secondly, in low income families, both single mothers and two-parent families, the pressure for parents to take on more paid work limited access to study time. In contrast, families with sufficient financial resources, usually from the father being in full time work, were able to 'buy' both time and space; for example, by organising child care or housekeeping support. Finally, financial circumstances also played into the quality of the space in terms of access to technology, both the number and quality of computers in the family and the ability to pay for higher quality internet access. More research is needed in New Zealand to explore the impact of these broader sociocultural contexts and in particular, to examine the intersections between socioeconomic status, gender, and family structure. 


\section{Conclusions}

Vaccaro and Lovell (2010) argue that "we should not settle for notions of engagement that fail to reflect the complicated lives of adult students' (p. 173). In highlighting the importance of space and time as a structural influence on mature aged students' engagement, the findings from the current study support this view. The quality of the space and time a student can access impacts on their behaviour, cognition, and emotion: the three dimensions of student engagement (Kahu, 2013). Insufficient time hinders the student from putting in the effort and behaviours necessary. Poor quality learning spaces, with interruptions from the family for example, make it difficult to achieve the levels of focus and concentration needed for deeper learning. And finally, stress and guilt stemming from other lifeload issues inhibit the student's ability to sustain interest and enthusiasm for their studies.

Trowler and Trowler (2010) argue that engagement requires a successful transition to university. The findings from this study suggest a critical element of that transition is learning to manage space and time. It has been suggested that one reason for the high drop out of first year distance students may be the cognitive overload of needing to learn technology skills as well as course content (Tyler-Smith, 2006). The current findings suggest there is a third load: learning to manage the space and time necessary for effective engagement. Importantly, while the task of integrating study with their other commitments is the student's responsibility (Kember, 1999), the university can help.

Three areas for improvement are suggested by the findings. Firstly, it is critical that course designers take into consideration the complexity of these students' lives and provide the flexibility they need. Higher education has been described as temporally rigid (Moss, 2006) and there is a very real risk that the increasing use of technology is eroding the flexibility that is historically central to distance study (Kirkwood, 2000). For example, Brad, who often had to go away for work, commented that one course had a test every week: 'you can't get ahead, you can't fall behind. You've got a test that's only available from Thursday 5 o'clock till 5 o'clock Sunday so, it doesn't make for very flexible studying.' Convenience for the university should not be prioritised above flexibility for distance students.

The second way the institution can assist is by revising the advice given to new students. Current advice tends to be too simplistic. It is not just a matter of allocating $x$ hours and setting up a desk. Instead, students need to be told this is a learning process and that they will need to trial different strategies to see what works for them and, importantly, what works for their family. The university in the current study provides a number of online tools to help students assess their time and lifeload prior to enrolment. However, none of these students had seen these tools and many were unaware of the workload expectations, suggesting more is needed. For example, use of such tools could be a compulsory part of the online enrolment process for distance students.

Finally, university support targeted at this particular aspect of the transition to university could be implemented. Orientation programmes tend to focus on academic preparedness and social 
integration. These findings suggest that for mature aged students, distance in particular, there is also a need to address the challenges that students will face in finding the necessary space and time in their lives. A related idea comes from Griffiths (2002) who set up a successful support group for students with family responsibilities, giving them an opportunity to discuss and share ideas. For distance students, this could be translated into the digital environment.

Although this research was conducted within a single university and its small sample size limits generalisability, qualitative work of this nature enables a richness of understanding that illuminates the complexity of the student experience. However, sociocultural context is important and so the experiences of these students may differ from those in other institutions and countries. Further research in New Zealand to more explicitly explore how gender, SES, family structure and ethnicity impact on access to space and time is needed. Of particular interest would be Maori research into this topic. Different cultural perspectives on family and community roles may lead to different challenges. Nevertheless, the issues raised will resonate to some degree with other mature aged distance students, if not with younger and internal students as well. All students have lives outside of university and will therefore experience conflicting demands at times.

Taking part in the research may have influenced these students' engagement with their study. While care was taken during the research not to directly influence their behaviour, reactivity, changes in participants' behaviour as a result of being part of a study, is a recognised threat to the validity of qualitative research (Onwuegbuzie \& Leech, 2007). In the present study not only were the participants observed, they were encouraged to reflect on their experiences and this may have helped them to resolve any problems they faced. However, while this may have made the transition a little easier for some participants, the challenges they faced and strategies they developed for managing their space and time as outlined in this paper are unlikely to be different to other students.

Study needs space and time. Successfully creating and managing space and time within complex lives is a difficult process for new students but one that is an important influence on the students' ability to engage with their studies. It is also therefore an important influence on student achievement and retention. Retaining flexibility, improving the messages students receive, and providing greater support for this learning process are three institution strategies that address this issue and will potentially reduce the high first year attrition rates in mature aged students. 


\section{References}

Alsop, R., Gonzalez-Arnal, S., \& Kilkey, M. (2008). The widening participation agenda: The marginal place of care. Gender and Education, 20, 623-637. doi: $10.1080 / 09540250802215235$

Ayres, R., \& Guilfoyle, A. (2008). Experiences of mature age female students studying psychology: A phenomenological account. In J. Renner, J. Cross \& L. McCormack (Eds.), Sustainability in higher education: Directions for change (pp. 46-59). Perth, Australia: Eden Cowan University.

Baxter, A., \& Britton, C. (2001). Risk, identity and change: Becoming a mature student. International Studies in Sociology of Education, 11(1), 87-102. doi: 10.1080/09620210100200066

Bird, J., \& Morgan, C. (2003). Adults contemplating university study at a distance: Issues, themes and concerns. The International Review of Research in Open and Distance Learning, 4(1), 1-15.

Braun, V., \& Clarke, V. (2006). Using thematic analysis in psychology. Qualitative Research in Psychology, 3, 77-101. doi: 10.1191/1478088706qp063oa

Brooks, R. (2012). Negotiating time and space for study: Student-parents and familial relationships. Sociology. doi: 10.1177/0038038512448565

Castles, J. (2004). Persistence and the adult learner: Factors affecting persistence in Open University students. Active Learning in Higher Education, 5(2), 166-179. doi:

$10.1177 / 1469787404043813$

Cheng, C. H., Wei, L. Y., \& Chen, Y. H. (2011). A new e-learning achievment evaluation model based on rough set and similarity filter. Computational Intelligence, 27(2), 260-279. doi: 10.1111/j.1467-8640.2011.00380.x

Christie, H., Munro, M., \& Wager, F. (2005). 'Day students' in higher education: Widening access students and successful transitions to university life. International Studies in Sociology of Education, 15(1), 3-30. doi: 10.1080/09620210500200129

Christie, H., Tett, L., Cree, V. E., Hounsell, J., \& McCune, V. (2008). 'A real rollercoaster of confidence and emotions': Learning to be a university student. Studies in Higher Education, 33(5), 567-581. doi: 10.1080/03075070802373040

Currie, J., \& Eveline, J. (2011). E-technology and work/life balance for academics with young children. Higher Education, 62(4), 533-550.

Denzin, N. K., \& Lincoln, Y. S. (2005). Introduction. In N. K. Denzin \& Y. S. Lincoln (Eds.), The Sage handbook of qualitative research ( $3^{\text {rd }}$ ed., pp. 1-32). Thousand Oaks, CA: Sage Publications.

Edwards, R. (1993). Mature women students: Separating or connecting family and education. London, UK: Taylor \& Francis. 
Ertl, H., \& Wright, S. (2008). Reviewing the literature on the student learning experience in higher education. London Review of Education, 6(3), 195-210. doi: 10.1080/14748460802489348

Fredricks, J. A., Blumenfeld, P., \& Paris, A. (2004). School engagement: Potential of the concept, state of the evidence. Review of Educational Research, 74(1), 59-109.

Gorard, S., Selwyn, N., \& Madden, L. (2003). Logged on to learning? Assessing the impact of technology on participation in lifelong learning. International Journal of Lifelong Education, 22(3), 281-296. doi: 10.1080/02601370304845

Griffiths, V. (2002). Crossing boundaries: The experiences of mature student mothers in initial teacher education. International Journal of Inclusive Education, 6(3), 267-285. doi: $10.1080 / 13603110110091607$

Henderson, R., Noble, K., \& De George-Walker, L. (2009). Transitioning into university: 'Interrupted' first year students problem-solving their way into study. Studies in Learning, Evaluation, Innovation and Development, 6(1), 51-65.

Jarvis, P., Holford, J., \& Griffin, C. (2003). The theory and practice of learning (2nd ed.). London, UK: Kogan Page.

Kahu, E. R. (2013). Framing student engagement in higher education. Studies in Higher Education, 38(5), 758-773. doi: 10.1080/03075079.2011.598505

Kaufman-Scarborough, C. (2006). Time use and the impact of technology examining workspaces in the home. Time and Society, 15(1), 57-80.

Kember, D. (1999). Integrating part-time study with family, work and social obligations. Studies in Higher Education, 24(1), 109-124. doi: 10.1080/03075079912331380178

Kirkwood, A. (2000). Learning at home with information and communication technologies. Distance Education, 21(2), 248-259. doi: 10.1080/0158791000210204

Lakoff, G., \& Johnson, M. (1980). Metaphors we live by. Chicago, IL: University of Chicago Press.

Lowe, J., \& Gayle, V. (2007). Exploring the work/life/study balance: the experience of higher education students in a Scottish further education college. Journal of Further and Higher Education, 31(3), 225-238. doi: 10.1080/03098770701424942

Ministry of Education. (2011). Education counts. Retrieved 12 July, 2011, from http://www.educationcounts.govt.nz/statistics/tertiary_education

Moss, D. (2004). Creating space for learning: Conceptualizing women and higher education through space and time. Gender and Education, 16(3), 283-302. doi:

$10.1080 / 09540250042000251452$

Moss, D. (2006). Gender, space and time: Women in higher education. Lanham, MD: Lexington Books.

Onwuegbuzie, A. J., \& Leech, N. L. (2007). Validity and qualitative research: An oxymoron? Quality and Quantity, 41, 233-249. doi: 10.1007/s11135-006-9000-3 
Redecker, C., Ala-Mutka, K., Bacigalupo, M., Ferrari, A., \& Punie, Y. (2009). Learning 2.0: The impact of Web 2.0 innovations on education and training in Europe. Luxembourg: Joint Research Centre, European Commission.

Rye, S. A. (2007). Flexibility, technology, and the daily life practices of distance students living beyond the digital mainstream. Geoforum, 38(5), 1028-1039. doi: http://dx.doi.org/10.1016/j.geoforum.2007.02.003

Sayer, A. (2000). Realism and social science. London, UK: Sage Publications.

Selwyn, N. (2011). 'Finding an appropriate fit for me': examining the (in)flexibilities of international distance learning. International Journal of Lifelong Education, 30(3), 367-383. doi: $10.1080 / 02601370.2011 .570873$

Servage, L. (2007). Just a minute sweetheart, Mom's writing a paper. Home, flexible learning, and learning biographies with uneven plots. Paper presented at the Adult Education Research Conference, Halifax, Canada.

Trowler, V., \& Trowler, P. (2010). Student engagement evidence summary. York, UK: The Higher Education Academy.

Tyler-Smith, K. (2006). Early attrition among first time elearners: A review of factors that contribute to drop-out, withdrawal and non-completion rates of adult learners undertaking elearning programmes. Journal of Online Learning and Teaching, 2(2), 73-85.

Urquhart, B., \& Pooley, J. (2007). The transition experience of Australian students to university: The importance of social support. The Australian Community Psychologist, 19(2), 78-91.

Vaccaro, A., \& Lovell, C. D. (2010). Inspiration from home: Understanding family as key to adult women's self-investment. Adult Education Quarterly, 60(2), 161-176. doi: $10.1177 / 0741713609336111$

White, S. (2008). Mothers who are student teachers: Navigating their dual roles in pre-service teacher education. Studies in Continuing Education, 30(2), 159-172. doi: $10.1080 / 01580370802102064$

Willig, C. (2001). Introducing qualitative research in psychology: Adventures in theory and method. Buckingham, UK: Open University Press.

Zembylas, M. (2008). Adult learners' emotions in online learning. Distance Education, 29(1), 71-87. doi: $10.1080 / 01587910802004852$

Zepke, N., Leach, L., \& Butler, P. (2011). Non-institutional influences and student perceptions of success. Studies in Higher Education, 36(2), 227-242. doi: 10.1080/03075070903545074 
Space and time to engage: Mature-aged distance students learn to fit study into their lives

Kahu, E

2014-02-21

http:/hdl.handle.net/10179/15155

22/04/2023 - Downloaded from MASSEY RESEARCH ONLINE 